\title{
The antihyperlipidaemic and hepatoprotective effect of Ipomoea batatas $L$. leaves extract in high-fat diet rats
}

\author{
Nurkhasanah Mahfudh, Nanik Sulistyani, Muhammad Syakbani, Athifah Candra Dewi \\ Faculty of Pharmacy, Universitas Ahmad Dahlan, Yogyakarta, Indonesia
}

\begin{tabular}{|c|c|}
\hline Article Info & ABSTRACT \\
\hline & \multirow{10}{*}{$\begin{array}{l}\text { The administration of high-fat diets can increase the body's lipid level and } \\
\text { damage the organs. Purple sweet potato leaf (Ipomoea batatas L.) was } \\
\text { reported as an antioxidant against free radicals. This study aimed to observe } \\
\text { the sweet potato leaf extract's activity on decreasing lipid profile and } \\
\text { hepatoprotective effect in high-fat diet fed rats. The treatment animals were } \\
\text { divided into five groups, namely normal control, high-fat diet (HFD) control, } \\
\text { the treatment group of purple sweet potato leaf extract (SPLE) doses } \\
100 \mathrm{mg} / \mathrm{kg} \mathrm{BW,} 200 \mathrm{mg} / \mathrm{kg} \text { BW and } 400 \mathrm{mg} / \mathrm{kg} \text { BW which fed with high-fat } \\
\text { diet for } 14 \text { days and SPLE for } 28 \text { days. After treatment was completed, the } \\
\text { blood was collected for the detection of cholesterol, triglyceride, serum } \\
\text { glutamic oxaloacetic transaminase (SGOT), and serum glutamic pyruvate } \\
\text { transaminase (SGPT). After that, the animals were sacrificed, and a liver } \\
\text { histopathology observation was conducted using Haematoxylien and Eosin } \\
\text { staining. The result showed a significant decrease in cholesterol and } \\
\text { triglyceride levels (p } \leq 0.05 \text { ) compared to the negative group in all treated } \\
\text { groups. The SGOT and SGPT enzymes in all of treatment groups were also } \\
\text { found to decrease compared with HFD control. The result was confirmed by } \\
\text { the histopathological observations. The finding suggested the potency of } \\
\text { SPLE for antihyperlipidaemic and hepatoprotective agent. }\end{array}$} \\
\hline Received Dec 20, 2020 & \\
\hline Revised May 20, 2021 & \\
\hline Accepted Jun 13, 2021 & \\
\hline Keywords: & \\
\hline & \\
\hline Cholesterol & \\
\hline Triglyceride & \\
\hline SGOT & \\
\hline SGPT & \\
\hline
\end{tabular}

This is an open access article under the CC BY-SA license.

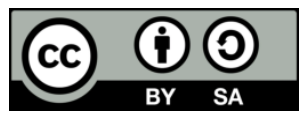

Corresponding Author:

Nurkhasanah Mahfudh

Faculty of Pharmacy

Universitas Ahmad Dahlan

Jl. Prof. Soepomo, Janturan, Yogyakarta, Indonesia

Email: nurkhasanah@pharm.uad.ac.id

\section{INTRODUCTION}

Hyperlipidemia is characterized by increased levels of total cholesterol, low density lipoprotein (LDL), triglycerides, and decreased high density lipoprotein (HDL). The high levels of blood lipids are well known as risk factors for cardiovascular disease [1]. The high level of lipid in the bloodstream has occurred following the high-fat diet. The small intestine absorbs fat from the diet and transfers it into chylomicrons, which are sent to peripheral tissues via the bloodstream [2].

The previous study found that elevated lipid levels were associated with increased liver enzymes [2], [3]. A high-fat diet can cause liver function disorders, which occurred by the accumulation of fat in the liver's hepatocytes, caused by an imbalance between the production and secretion of triglycerides by the liver. The increase in the liver's fatty acids beyond its capacity will trigger free radicals and lead the liver cell damage. One of the liver cell damage markers is the increase of SGOT and SGPT in the blood [4].

The leaves of purple sweet potato (Ipomoea batatas L.) were interesting to be studied. The previous report showed that giving Ipomoea batatas L extract can reduce cholesterol, triglyceride levels, and increase 
plasma HDL in diabetic rats [5]. The study on high-fat diet rats with long 35 days of treatment was found to affect lipid metabolism [6]. The treatment of sweet potato was also reported to decrease the hepatic oxidative stress in hyperlipidemic rats [7].

There are many varieties and cultivars of sweet potato. The varieties were characterized by the size, shape, and color of the tuber. The different colours of the tuber, the different chemical content. The different concentration of phenolic and carotenoid content in different cultivar of Ipomoea batatas gives a different activity [8]. The present study used the purple sweet potato. The purple colour of sweet potato indicates anthocyanin's high content, which is reported as a strong antioxidant. This study's objective was to investigate the effect of sweet purple potato leaves extract on decreasing lipid profile and the hepatoprotectife effect in the hyperlipidaemic rats.

\section{RESEARCH METHOD}

\subsection{Plant collection and authentication}

Purple sweet potato leaves were obtained from Magelang, Indonesia in May 2019. The authentication of the sample was carried out in the Laboratory of Biology, Universitas Ahmad Dahlan. The purple sweet potato leaves were separated from the stem and washed with water, then dried and ground. The powder of purple sweet potato leaves was sieved with siever no 20.

\subsection{Extraction}

The purple sweet potato leaves were extracted using $70 \%$ ethanol $(1: 4 \mathrm{v} / \mathrm{v})$ by the maceration method. The filtrate was evaporated using a rotary evaporator with a temperature of $60^{\circ} \mathrm{C}$ to get concentrated extract.

\subsection{Animal test}

The test animals which were used in this study were two month old male Wistar rats, with 150-200 gram body weight. The animal handling and procedure in this study was approved by the Research Ethics Committee of Universitas Ahmad Dahlan with a reference number 011904031. Before the treatment, the animasl were acclimatized for seven days and fed with BR II standard food.

\subsection{Preparation of high-fat feed}

The high-fat feed was made by mixing 300 gram of standard food BR II, 20 gram chicken egg yolk, 100 gram butter, 10 gram beef fat, and $0.05 \%$ propylthiouracil (PTU). All ingredients were mixed homogenously, then formed into pellets and dried using an oven at $50^{\circ} \mathrm{C}$.

\subsection{Animal treatment}

The extract was suspended in the CMC Na $1 \%$ to make it homogenously. The animals were divided into five groups, they were randomly selected, and each group consisted of five rats.

Group I: Normal control group, the animals were given BR II standard feed.

Group II: Negative control group, the animals were fed a high-fat diet for 14 days and sodium carboxy methyl cellulose (CMC-Na) $1 \%$ for 28 days.

Group III: Test animal groups were given a high-fat diet for 14 days and ethanol extract of purple sweet potato leaves (SPLE) orally at a dose of $100 \mathrm{mg} / \mathrm{kg}$ BW for 28 days.

Group IV: Test animal groups were given a high-fat diet for 14 days, and ethanol extract of purple sweet potato leaves (SPLE) orally at a dose of $200 \mathrm{mg} / \mathrm{kg} \mathrm{BW}$ for 28 days.

Group V: Test animal groups were given a high-fat diet for 14 days, and ethanol extract of purple sweet potato leaves (SPLE) orally at a dose of $400 \mathrm{mg} / \mathrm{kg}$ BW for 28 days.

\subsection{Blood sampling}

Blood samples of Wistar rats were taken in day 29 after the administration of sweet potato leaves ethanol extract. The rats were fasted for approximately 12 hours before taking blood samples. Blood was drawn by holding the mouse and clamped at the nape of the neck and fingers. The blood was taken from the retro-orbital plexus using a capillary tube and centrifuged for 10 minutes at a speed of 12,000 RPM. Next, blood serum was separated for the measurement of cholesterol, triglyceride, SGOT, and SGPT levels using the Diasys ${ }^{\circledR}$ kit. The protocol of the test followed the manufacturer's instructions.

\subsection{Percentage of SGOT and SGPT activity}

The hepatoprotective effect of treatment was evaluated by calculating of percentage of reduction according to formula:

$\%$ reduction $=$ value of SGOT/SGPT in negative control-value of SGOT/SGPT in treatment group Value of SGOT/SGPT in negative control 


\subsection{Histopathological observation}

The test animals were anesthetized using $\mathrm{CO}_{2}$ gas, and then the mice were dissected in the abdomen. The liver was taken and washed with $0.9 \% \mathrm{NaCl}$. Then, histopathological preparations were made based on the Kiernan method [9]. The liver organ were sliced and stained by Haematoxylin and Eosin. The observations of the histopathologic organ were done by microscope qualitatively.

\section{RESULTS AND DISCUSSION}

\subsection{The body weight gain profile}

Obesity is considered a significant risk factor for some chronic diseases such as hypertension, type 2 diabetes, and cardiovascular diseases [10]. The prevalence of obesity has become increasing around the world. Dietary fat intake is considered to be an important factor for increasing the body weight and lipid profile in the body [11]. The study in animal models was also found that diets rich in fat induce obesity in animal models, both in rats and mice [12].

Besides the high-fat diet, treatment with propylthiouracil (PTU) could accelerate the increase of body weight and formation of lipids. Propylthiouracil (PTU), which is used as an antithyroid medication, can reduce the blood's thyroid level, causing hypothyroidism. Hypothyroidism affects lipoprotein metabolism by reducing the number of LDL receptors, resulting in an increase in LDL in the blood and resulting in the formation of cholesterol [13], [14]. The body weight progress of animals in the control group and treatment group were presented in Figure 1.

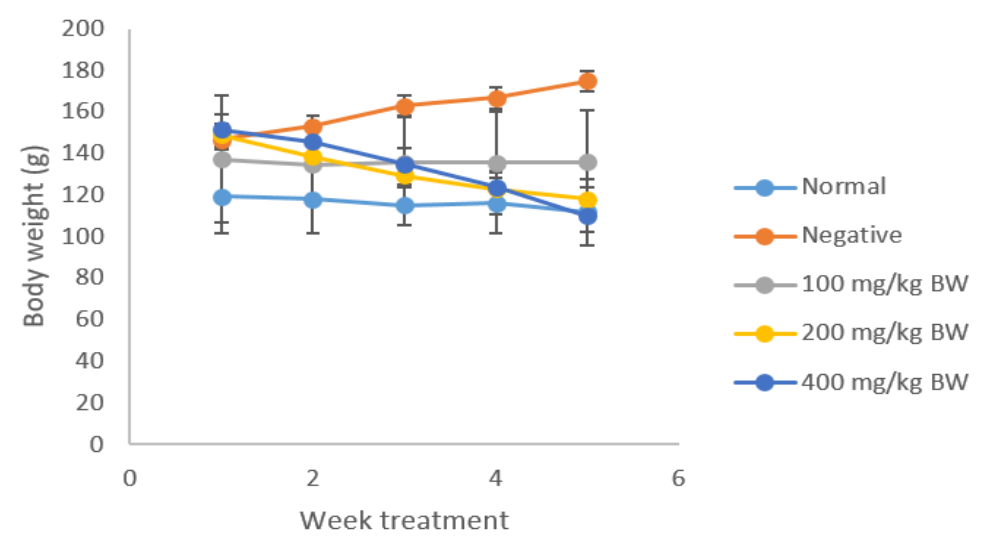

Figure 1. The increase of rat body weight treated with various dosage $(100,200$, and $400 \mathrm{mg} / \mathrm{kg} \mathrm{BW})$ of sweet potato leaves extract (SPLE)

The treatment with SPLE on high-fat diet fed rats inhibits the weight gain caused by the high-fat diet. The provision of a high-fat diet causes an increase in free fatty acids that accumulate in the tissue and will increase acyl-CoA and its metabolites, including diacylglycerol (DAG), and triacylglycerol (TAG). This accumulation can trigger an increase in glucose uptake to tissues and glycogenesis, causing an increase in body mass [10] and hyperlipidemia [15]. The treatment with SPLE reduces the increase of body weight significantly compared to the negative control.

The present study found that treatment with SPLE could inhibit the increase of body weight significantly compared to the negative control. Sweet potato leaves was reported as a high nutritional food with high fiber content [16]. Sweet potato leaves are also recommended as a functional food with antioxidant activity with a high content of polyphenol content. The high content of fiber and antioxidant activity of sweet potato leaves could play an important role in inhibiting body weight gain.

\subsection{Treatment with SPLE reduce the blood lipid}

The high-fat feeding for 14 days was also found to increase the cholesterol and triglyceride levels compared to the normal group as shown in Table 1. High fat consumption can increase acetyl-CoA production. The increase in acetyl-CoA affects fatty acid formation and subsequently increases the synthesis of fat into cholesterol. The saturated fatty acids in HFD will increase LDL levels by lowering the LDL receptors in the liver, thereby reducing the disposal of LDL in the blood and increasing LDL in the blood. When LDL increases, there will be an increase in total cholesterol levels [17]. The increase in total 
cholesterol was followed by increasing in triglyceride levels. The previous study also was found that treatment with a high-fat diet increased the triglyceride level higher than the high carbohydrate diet in the rat [18], [19].

Treatment of SPLE on hyperlipidemic rats showed to decrease in both the total cholesterol and triglyceride levels significantly $(\mathrm{p}<0.05)$. The higher dose treatments cause the bigger decreasing of cholesterol total and triglyceride. The treatment of SPLE $400 \mathrm{mg} / \mathrm{kg} \mathrm{BW}$ give the value of total cholesterol less than normal group significsntly, but the value is still in the normal range of total cholesterol in wistar rat 10-54 mg/dL [20]. The decreasing of triglyceride after treatment with SPLE $400 \mathrm{mg} / \mathrm{kg}$ BW was also less than normal group, but it was still in the normal range $(26-145 \mathrm{mg} / \mathrm{dL})$ [21]. The high content of polyphenol in the SPLE plays an important role in this effect through the antioxidant effect [22]. The polyphenol prevents the oxidation of LDL cholesterol by binding to free radicals and transitioning metal ions to inhibit lipid peroxidase [23]. Lipid peroxidase plays a role in the formation of free radicals in the formation of fatty acids. Treatment with SPLE with flavonoid content can inhibit the formation of acetyl-CoA in the fatty acid biosynthesis. Flavonoids also inhibit cholesterol absorption, increased bile excretion, and 3-hydroxy-3methylglutaryl-CoA (HMG-CoA) inhibition [24]. Flavonoids also reported to have strong activity in inhibiting lipid peroxidase by inhibiting the activity of the acyl-coenzyme: Cholesterol acyltransferase (ACAT), which plays a role in cholesterol esterification in the intestine and liver and inhibits the activity of the enzyme 3-hydroxy-3-methyl-glutaril-CoA, which results in inhibition of cholesterol synthesis [24]. Another phenolic content in the SPLE, including tannin, also involves decreasing cholesterol and triglyceride level through the inhibition of lipid absorption. The protein and lipids contained in the feed may be deposited by the tannins in the SPLE so that the absorption of lipid from the feed is disturbed. The previous study also showed a similar result [19], [25].

Table 1. The total cholesterol and triglyceride level of sweet potato leaves extract-treated rats induced by high-fat feeding

\begin{tabular}{lcc}
\hline Groups & Cholesterol level $(\mathrm{mg} / \mathrm{dL})$ & Triglyceride level $(\mathrm{mg} / \mathrm{dL})$ \\
\hline I (Normal) & $30.36 \pm 9.24^{\#}$ & $55.49 \pm 7.02^{\#}$ \\
II (Negative) & $74.46 \pm 6.13^{*}$ & $174.13 \pm 1.47^{*}$ \\
III (SPLE 100 mg/kg BW) & $55.96 \pm 3.21^{\#^{*}}$ & $131.88 \pm 2.64^{\#^{*}}$ \\
IV (SPLE 200 mg/kg BW) & $28.25 \pm 3.88^{\#}$ & $72.48 \pm 2.58^{\#^{*}}$ \\
V (SPLE 400 mg/kg BW) & $19.28 \pm 2.67^{\#^{*}}$ & $43.91 \pm 2.17^{\#^{*}}$ \\
\hline (*) showed significantly different from the normal group $(\mathrm{p}<0.05)$ \\
(\#) showed significantly different from the negative control group ( $(\mathrm{p}<0.05)$
\end{tabular}

\subsection{Treatment of SPLE prevent liver damage}

The provision of a high-fat diet can cause liver dysfunction, one of which is the accumulation of fat in the liver's hepatocytes (fatty liver disease) [18], [26]. The fatty liver disease such as steatohepatitis leads to fibrosis, cirrhosis, and eventually hepatocellular carcinoma. This is caused by an imbalance between the production and secretion of triglycerides by the liver. The most common cause of fatty liver accumulation is increasing fatty acids in the liver that exceeds its oxidative capacity. It will trigger the formation of free radicals, which could lead to necrosis of hepatocytes and other liver damage that will increase the activity of the SGOT and SGPT enzymes in the blood, which is a marker of liver damage [27].

The increase of fatty acids in the blood will be carried to the liver to undergo an oxidation process. The excess of fatty acids is stored in the form of triglycerides. The accumulation of triglycerides will increase TNF- $\alpha$ and be followed by an increase in nicotinamide adenine dinucleotide phosphate (NADPH) oxidase, which will produce superoxide radicals. These radical species are highly reactive to lipids and causing lipid peroxidation. Lipid peroxidation will cause changes in the permeability of the liver cells, which causes the enzymes produced by liver cells, especially serum glutamate pyruvate transferase (SGPT) serum glutamate oxaloacetate transaminase (SGOT) to increase in the blood [28]. This current study found that high-fat feeding induction could increase the SGOT and SGPT activity level as shown in Table 2, due to the accumulation of lipids in the liver and lead to produce free radicals species [29].

Table 2. The SGOT and SGPT activity level in the hyperlipidemic rats treated with sweet potato (Ipomoe batatas $L$.) leaves extract

\begin{tabular}{|c|c|c|}
\hline Groups & SGOT activity (U/L) & SGPT activity (U/L) \\
\hline I (Normal) & $66.96 \pm 10.39^{\#}$ & $21.67 \pm 6.12^{\#}$ \\
\hline II (Negative) & $147.84 \pm 65.09^{*}$ & $49.82 \pm 11.80^{*}$ \\
\hline III (SPLE 100 mg/kg BW) & $79.90 \pm 22.60^{\# *}$ & $29.12 \pm 5.49^{\# *}$ \\
\hline IV (SPLE $200 \mathrm{mg} / \mathrm{kg} \mathrm{BW}$ ) & $68.58 \pm 16.75^{\#}$ & $19.41 \pm 8.33^{\#}$ \\
\hline $\mathrm{V}$ (SPLE $400 \mathrm{mg} / \mathrm{kg} \mathrm{BW})$ & $44.32 \pm 5.67^{\# *}$ & $14.23 \pm 3.51^{\# *}$ \\
\hline
\end{tabular}


The present study found that treatment of SPLE on hyperlipidemic rats could reduce the SGOT and SGPT activity level significantly shown in Table 2. One of the compounds contained in the SPLE is quercetin, which has an antioxidant effect as free radicals scavenger to protect the liver from oxidative damage. Quercetin decreases the activity of the SGOT and SGPT enzymes due to its activity as a scavenger. As a scavenger, quercetin can prevent and reduce liver damage due to oxidative stress and prevent oxidative damage such as lipid peroxidation and oxidized deoxyribonucleic acid (DNA), by acting as a scavenger of reactive oxygen species (ROS) produced due to high-fat feeding [18], [26].

The effectivity of SPLE in protecting of liver damage from high-fat induction was presented on Table 3. The SPLE has a hepatoprotective effect through inhibiting free radicals production due to high-fat induction. The protective effect of SPLE increases by increasing dose treatment. The value of SGPT and SGOT in a group of SPLE $200 \mathrm{mg} / \mathrm{kg} \mathrm{BW}$ was not significantly different with normal group. Treatment with $200 \mathrm{mg} / \mathrm{kg} \mathrm{BW}$ of SPLE gives the best result in decreasing of SGPT and SGOT.

Table 3. The protective effect of sweet potato leaves extract on hepatotoxicity caused by high-fat induction

\begin{tabular}{ccc}
\hline Groups & \% reduction of SGOT activity & \% reduction of SGPT activity \\
\hline SPLE $100 \mathrm{mg} / \mathrm{kg} \mathrm{BW}$ & 45.96 & 41.55 \\
SPLE $200 \mathrm{mg} / \mathrm{kg} \mathrm{BW}$ & 53.61 & 61.04 \\
SPLE $400 \mathrm{mg} / \mathrm{kg} \mathrm{BW}$ & 70.02 & 71.44 \\
\hline
\end{tabular}

\subsection{Histopathologic profile}

The histopathological observation was carried out to confirm the effect of SPLE in repairing the liver function. Treatment with SPLE decreases liver damage due to high-fat feeding induction, as presented in Figure 2 and Table 4.

Table 4. The degree of liver damage of sweet potato leaves extract treated hyperlipidemic rats

\begin{tabular}{lccc}
\hline Groups & \multicolumn{3}{c}{ Degree of cell damage } \\
& normal & Fatty degeneration & necrosis \\
\hline I (Normal) & +++ & - & + \\
II (Negative) & + & ++ & + \\
III (SPLE 100 mg/kg BW) & ++ & + & + \\
IV (SPLE 200 mg/kg BW) & +++ & - & + \\
V (SPLE 400 mg/kg BW) & ++ & + & + \\
\hline
\end{tabular}

The result showed that the degree of fatty degeneration cell in the SPLE treated group Figure 2c-2e was decreased compare to negative control Figure $2 b$. The fatty degeneration was not occurred in the normal group Figure 2a. The result was confirmed by previous research [30], [31]. The activity level of SGOT and SGPT in diabetic rats was also decreased after being treated with Ipomoea batatas L. leaves extract.

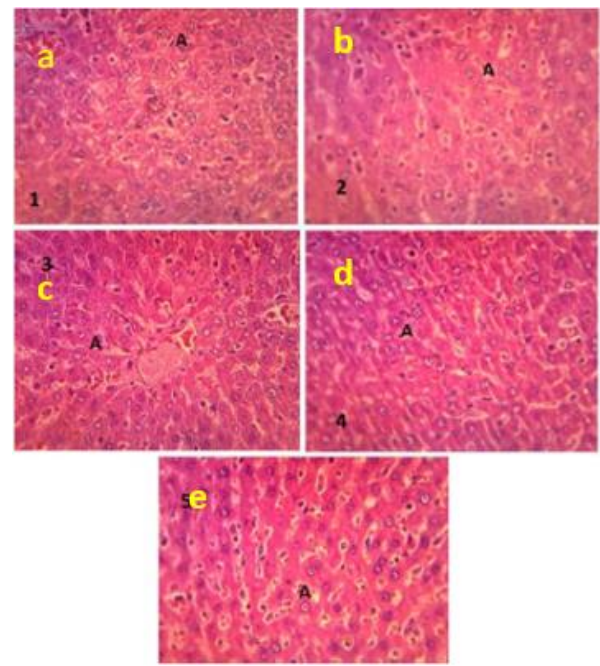

Figure 2. The histopathological observation of hyperlipidemic rat liver treated with sweet potato leaves extract with variuos doses; (a) normal, (b) negative control, (c) $100 \mathrm{mg} / \mathrm{kg} \mathrm{BW}$, (d) $200 \mathrm{mg} / \mathrm{kg} \mathrm{BW}$, (e) $400 \mathrm{mg} / \mathrm{kg} \mathrm{BW}$ 


\section{CONCLUSION}

Treatment with sweet potato leaves extract on the hyperlipidaemic rat decreases the blood lipid profile (total cholesterol and triglyceride) and protects the liver from damage due to high-fat feeding induction. Thus, sweet potato leaves could be developed as functional food to prevent from hyperlipidemia as well as for hepatoprotective induced by hyperlipid.

\section{ACKNOWLEDGEMENTS}

The authors thank the Ministry of Research Technology and innovation for funding this research through the Master Theses Research scheme 2020.

\section{REFERENCES}

[1] R. H. Nelson, "Hyperlipidemia as a Risk Factor for Cardiovascular Disease," Prime Care, vol. 40, no. 1, pp. 195211, 2013, doi: 10.1016/j.pop.2012.11.003.Hyperlipidemia.

[2] F. Nouh, M. Omar, and M. Younis, "Risk Factors and Management of Hyperlipidemia (Review)," Asian J. Cardiol. Res., vol. 2, no. 1, pp. 1-10, 2019, doi: 10.9734/AJCR/2019/45449.

[3] N. Al-jameil, F. A. Khan, S. Arjumand, M. F. Khan, and H. Tabassum, "Associated liver enzymes with hyperlipidemic profile in type 2 diabetes patients," Int. J. Clin. Exp. Pathol., vol. 7, no. 7, pp. 4345-4349, 2014.

[4] A. Adetutu and A. O. Owoade, "Hepatoprotective and Antioxidant Effect of Hibiscus Polyphenol Rich Extract (HPE) Against Carbon Tetrachloride ( CCL 4 ) - Induced Damage in Rats," Br. J. Med. Med. Res., vol. 3, no. 4, pp. 1574-1586, 2013.

[5] I. P. P. D. Heriwijaya, I. M. Jawi, and B. K. Satriyasa, "Uji efektivitas ekstrak air daun ubi jalar ungu (Ipomoea batatas) terhadap profil lipid tikus putih jantan galur wistar yang diinduksi pakan dislipidemia," Intisari Sains Medis, vol. 11, no. 2, p. 452, 2020, doi: 10.15562/ism.v11i2.584.

[6] R. Kurata, T. Kobayashi, T. Ishii, and M. Kishimoto, "Influence of Sweet Potato (Ipomoea batatas L.) Leaf Consumption on Rat Lipid Metabolism," Food Sci. Technol. Res., vol. 23, no. 1, pp. 57-62, 2017, doi: 10.3136/fstr.23.57.

[7] W. Chen et al., "Effect of purple sweet potato on lipid metabolism and oxidative stress in hyperlipidemic rats," $J$. Zhejiang Univ. Med. Sci., vol. 40, no. 4, pp. 360-364, 2011.

[8] Y. Tang, W. Cai, and B. Xu, "Profiles of phenolics, carotenoids and antioxidative capacities of thermal processed white, yellow, orange and purple sweet potatoes grown in Guilin, China," Food Sci. Hum. Wellness, vol. 4, no. 3 , pp. 123-132, 2015, doi: 10.1016/j.fshw.2015.07.003.

[9] Z. Kmiec, "J.A. Kiernan. Histological and Histochemical Methods: Theory and Practice. 5th edition, Scion Publishing, 2015, 571 pp.," Folia Histochem. Cytobiol., vol. 54, no. 1, pp. 58-59, 2016, doi: 10.5603/fhc.a2016.0007.

[10] K. M. Gadde, C. K. Martin, H. R. Berthoud, and S. B. Heymsfield, "Obesity: Pathophysiology and Management," J. Am. Coll. Cardiol., vol. 71, no. 1, pp. 69-84, 2018, doi: 10.1016/j.jacc.2017.11.011.

[11] F. Barkas, T. Nomikos, E. Liberopoulos, and D. Panagiotakos, "Diet and cardiovascular disease risk among individuals with familial hypercholesterolemia: Systematic review and meta-analysis," Nutrients, vol. 12, no. 8, pp. 1-22, 2020, doi: 10.3390/nu12082436.

[12] S. Parasuraman and L. E. Wen, "Animal Model for Obesity-An Overview," Syst. Rev. Pharm., vol. 6, no. 1, pp. 9 12,2015

[13] J. H. H. Al-awadi, "Hypothyroidism and High Fat Diet Could Accelerates obesity and Aggravates inflammation in Albino Rats," J. Biol., no. September, pp. 1-14, 2016.

[14] S. Singh, V. Panda, S. Sudhamani, and P. Dande, "Protective effect of a polyherbal bioactive fraction in propylthiouracil-induced thyroid toxicity in ratsby modulation of the hypothalamic-pituitary-thyroid and hypothalamic-pituitary-adrenal axes," Toxicol. Reports, vol. 7, no. July 2019, pp. 730-742, 2020, doi: 10.1016/j.toxrep.2020.06.002.

[15] K. Sikder, S. K. Shukla, N. Patel, H. Singh, and K. Rafiq, "High Fat Diet Upregulates Fatty Acid Oxidation and Ketogenesis via Intervention of PPAR- $\gamma$," Cell. Physiol. Biochem., vol. 48, no. 3, pp. 1317-1331, 2018, doi: $10.1159 / 000492091$.

[16] H. Sun, T. Mu, L. Xi, M. Zhang, and J. Chen, "Sweet potato (Ipomoea batatas L.) leaves as nutritional and functional foods," Food Chem., vol. 156, pp. 380-389, Aug. 2014, doi: 10.1016/j.foodchem.2014.01.079.

[17] D. F. Coelho et al., "Effect of high-fat diets on body composition, lipid metabolism and insulin sensitivity, and the role of exercise on these parameters," Brazilian J. Med. Biol. Res., vol. 44, no. 10, pp. 966-972, Oct. 2011, doi: 10.1590/S0100-879X2011007500107.

[18] M. A. Al Mamun et al., "High carbohydrate high fat diet induced hepatic steatosis and dyslipidemia were ameliorated by psidium guajava leaf powder supplementation in rats," Evidence-based Complement. Altern. Med., vol. 2019, pp. 1-12, 2019, doi: 10.1155/2019/1897237.

[19] C. Artha, A. Mustika, and S. W. Sulistyawati, "Singawalang Leaf Extract Effects on LDL Levels of Hypercholesterolemic Male Rats," e-Journal Kedokt. Indones., vol. 5, no. 2, pp. 105-109, 2017.

[20] R. Asija, C. Singh, and Hemlata, "A Comprehensive Review on Antihyperlipidemic Activity of Various A Comprehensive Review on Antihyperlipidemic Activity of Various Medicinal Plants," Int. J. Curr. Pharm. Rev. Res., vol. 7, no. 6, pp. 407-415, 2016. 
[21] N. Mahfudh and N. Ikarini, "In vivo effect of sub-chronic administration of ethanol extract of Rosella ( Hibiscus sabdariffa L .) calyx on total blood cholesterol, triglyceride level, and heart histopathologic profile," Int. Food Res. $J$. , vol. 25, no. 3, pp. 1253-1257, 2018.

[22] S. Hue, A. N. Boyce, and C. Somasundram, "Comparative Study on the Antioxidant Activity of Leaf Extract and Carotenoids Extract from Ipomoea batatas var. Oren (Sweetpotato) Leaves,” Int. J. Nutr. Food Eng., vol. 5, no. 10, pp. 604-607, 2011.

[23] R. N. I. Siregar, "The Effectof Eugenia polyantha Extrac on LDL," J Major., vol. 4, no. 5, pp. 85-92, 2015.

[24] F. D. Lairin, D. Lyrawati, and S. Soeharto, "Ekstrak Daging Putih Semangka (Citrulus vulgaris) Menurunkan Kolesterol Total dan Aktivitas Hidroksi-Metilglutaril-KoA Reduktase Tikus Hiperkolesterolemia,” J. Kedokt. Brawijaya, vol. 29, no. 2, pp. 104-109, 2016, doi: 10.21776/ub.jkb.2016.029.02.2.

[25] A. G. Elfadhl, M. K. Sabahelkhier, M. Y. Rayan, M. O. Daa, A. H. Nagla, and S. B. Israa, "Effect of Tannin and Plant Tannins on some Organs and Physic-Chemical Characters of Diabetic Wistar," Int. J. Adv. Res., vol. 1, no. 10, pp. 165-170, 2013.

[26] D. Kumar, D. K. Dwivedi, M. Lahkar, and A. Jangra, "Hepatoprotective potential of 7,8-Dihydroxyflavone against alcohol and high-fat diet induced liver toxicity via attenuation of oxido-nitrosative stress and NF- $\mathrm{B}$ activation," Pharmacol. Reports, vol. 71, no. 6, pp. 1235-1243, Dec. 2019, doi: 10.1016/j.pharep.2019.07.002.

[27] W. Widarti and N. Nurqaidah, "Analisis Kadar Serum Glutamic Pyruvic Transaminase (Sgpt) Dan Serum Glutamic Oxaloacetic Transaminase (Sgot) Pada Petani Yang Menggunakan Pestisida," J. Media Anal. Kesehat., vol. 10, no. 1, p. 35, 2019, doi: 10.32382/mak.v10i1.984.

[28] J. Yang et al., "Oxidative stress and non-alcoholic fatty liver disease: Effects of omega-3 fatty acid supplementation," Nutrients, vol. 11, no. 4, pp. 1-37, 2019, doi: 10.3390/nu11040872.

[29] P. M. Rindler, S. M. Plafker, L. I. Szweda, and M. Kinter, "High dietary fat selectively increases catalase expression within cardiac mitochondria," J. Biol. Chem., vol. 288, no. 3, pp. 1979-1990, 2013, doi: 10.1074/jbc.M112.412890.

[30] O. O. Ogunrinola, O. O. Fajana, S. N. Olaitan, O. B. Adu, and M. O. Akinola, "Anti-diabetic activity of Ipomoea batatas leaves extract: Effects on hepatic enzymes in alloxan-induced diabetic rats," Res. J. Med. Plant, vol. 9, no. 5, pp. 227-233, 2015, doi: 10.3923/rjmp.2015.227.233.

[31] S. Pal, S. Gautam, A. Mishra, R. Maurya, and A. K. Srivastava, "Antihyperglycemic and antidyslipidemic potential of ipomoea batatas leaves in validated diabetic animal models," Int. J. Pharm. Pharm. Sci., vol. 7, no. 7, pp. 176186,2015 